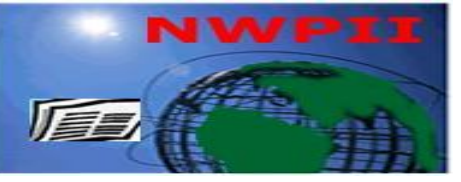

American Journal of Biomedical Sciences

ISSN: 1937-9080

nwpii.com/ajbms

\title{
Studies on the Development of a Non-genetic Obese Type 2 Diabetic Rat Model: Amelioration by (+)-Catechin Hydrate
}

\author{
Pranav Mehra $^{1}$, Ashwani Koul ${ }^{2}$, Devi Dayal Bansal ${ }^{*}$ \\ ${ }^{1}$ Department of Biochemistry, Panjab University, Chandigarh-160014, India. \\ ${ }^{2}$ Department of Biophysics, Panjab University, Chandigarh-160014, India. \\ *Corresponding author \\ Dr. Devi Dayal Bansal \\ Department of Biochemistry \\ Basic Medical Sciences Block \\ Panjab University, Chandigarh-160014. \\ INDIA \\ Telephone: (O) +91-172-2534131; (M): +919814911579 \\ Email: bansal_devi@yahoo.com
}

\begin{tabular}{l|l|l} 
Received: 21 June 2010; & Revised: 1 July 2010; & Accepted: 7 July 2010
\end{tabular}

\begin{abstract}
This study was planned to investigate the effect of pure catechin, a green tea flavonoid on the levels of fasting plasma glucose, plasma insulin, plasma and tissue lipids in high fat high sucrose diet fed rats for a period of 12 weeks. The results indicate that feeding the rats with high fat and high sucrose diet resulted into the development of an obese type 2 diabetic rat model and (+)-catechin hydrate to some extent prevented the weight gain, rise in blood glucose, cholesterol and Triglyceride levels. Insulin levels were also high in high fat high sucrose fed rats as compared to rats fed high fat, high sucrose and administered (+)-catechin hydrate. Catechin also prevented the weight gain in control group thereby limiting its role only in obesity. Catechin supplementation in rats fed high fat and high sucrose diet was also found to prevent increase in cholesterol, triglycerides and glycolipid levels in liver and cholesterol and glycolipid levels in heart. In conclusion high fat and high sucrose diet is useful in the development of an obese type 2 diabetic rat model and catechin to some extent is beneficial.
\end{abstract}

Keywords: (+)-catechin hydrate; liver; heart; triglyceride; cholesterol.

\section{Introduction}

We have previously developed an insulin resistant rat model by chronic feeding of low magnesium and high sucrose diet. This was a nongenetic non obese model [1]. The major cause of insulin resistance in this model was high sucrose Am. J. Biomed. Sci. 2010, 2(4), 352-364; doi: 10.5099/aj100400352 diet. It was presumed that a combination of high fat and high sucrose diet will lead to the development of an obese type 2 diabetic rat model as it is well known that refined sugars and fats have a number of detrimental effects. High sucrose feeding stimulates hepatic lipogenesis by increasing the activity of some enzymes like acetyl CoA carboxylase [2] which contributes to (๑) 2010 by NWPII. All rights reserved. 
increase in plasma triglycerides, total cholesterol, LDL-Cholesterol and decreases HDL-Cholesterol. Hyperlipidemia is one of the major risk factors in the development of atherosclerosis and cardiovascular diseases. Constant hyperlipidemia caused by high fat diet and hormonal imbalance can cause increased thickening of blood leading to blocked blood vessels, obesity, stiffness of heart muscle lining, glycosylation of hemoglobin increasing the risk of heart attack [3] and oxidation of LDL causing atherosclerosis [4].

Green tea obtained from the leaves of Camellia sinensis is a widely consumed beverage in Asia and is known for its health promoting effects [5]. Epidemiological studies have shown a significant inverse relationship between the consumption of green tea beverages and plasma lipid concentration $[6,7,8]$. It has been suggested that green tea consumption prevents type 2 diabetes [9]. The amelioration of insulin resistance by green tea is associated with increased expression levels of glucose transporter IV in fructose fed diabetic rats [10].

Green tea extract contains polyphenols especially flavanols and flavonols which can constitute $30 \%$ of fresh leaf dry weight [5], teanins and caffeine. Catechins (e.g., catechin, epicatechin, epigallocatechin and their gallates) are predominant form of flavanols present in green tea and have been shown to cause hypoglycemia by enhancing insulin stimulated glucose uptake in rat adipocytes [11], by reducing serum glucose levels in alloxan diabetic rats [9] and by inhibiting glucose uptake in the intestine by inhibition of sodium-dependent glucose transporter in rabbit intestinal epithelial cells [12]. Catechins are particularly known for their anti-diabetic [11], anti-inflammatory [13], anti-oxidative [14], anticancerous [15] and neuroprotective [16] effects and it is known that hypolipidemic effect of most abundant catechin (-)-epigallocatechin gallate (EGCG) is due to enhanced removal of intravenously injected ${ }^{14} \mathrm{C}$-Cholesterol from plasma of rats [17], inhibition of cholesterol absorption [18], or increase in LDL receptor expression [19].

Despite a preponderance of data on the effect of green tea and its active components in combating hyperlipidemia, there is virtually no information regarding the effects of pure catechin $(+)$-catechin hydrate. So we focused our study in exploring in vivo effects of (+)-catechin hydrate on body weight and plasma parameters viz. glucose, triglycerides, cholesterol, insulin and liver and heart tissue lipids in control and high fat high sucrose diet fed rats.

\section{Materials and Methods}

\subsection{Reagents}

(+)-Catechin hydrate was purchased from Sigma-Aldrich Company, USA for in vivo experiments. All other analytical grade laboratory chemicals and reagents were purchased from Merck (Germany) or SRL Chemicals (India). Ultra pure water prepared by labPURE-series Analytical \& Ultraplusuf (BIO-AGE, Mohali, India) was used throughout the experiment. The preparations were made fresh every time before the commencement of the experiment.

\subsection{Animals}

Studies were carried out in Male Wistar rats, each weighing approximately 100-120 g. These animals were obtained from central animal house, Panjab University, Chandigarh. The animals were housed in polypropylene cages in hygienic conditions with rice husk bedding and, had free access to tap water. Before giving experimental diet, rats were provided a standard rodent lab chow for a 2 week baseline period. Throughout the experiment, all the procedures and care of the animals were conducted in accordance with institutional guidelines and CPCSEA policies (Committee For The Purpose Of Control and Supervision of Experiments on Animals).

\subsection{Experimental design}

After the completion of the baseline period, rats were given respective assigned diet prepared in the laboratory (Table 1). Rats were randomly divided into the following groups: Control diet (CD), Control diet \& (+)-Catechin hydrate (CD $+\mathrm{CH})$, High fat \& high sucrose diet (HFHS), High fat \& high sucrose along with (+)-catechin hydrate (HFHS + CH). (+)-Catechin hydrate was solubilized in hot distilled water $\left(70^{\circ} \mathrm{C}\right)$ and this solution at room temperature was orally 
administered to respective experimental groups with the help of canula at a dose of $110 \mathrm{mg} / \mathrm{kg}$ body weight. Rats were provided free access to experimental diet for the period of 12 weeks.

Table 1. Composition of experimental diet

\begin{tabular}{|c|c|c|}
\hline Ingredient & $\begin{array}{l}\text { Control diet } \\
\text { (CD) (g) }\end{array}$ & $\begin{array}{l}\text { High fat \& High Sucrose } \\
\text { diet } \\
\text { (HFHS) (g) }\end{array}$ \\
\hline Starch & 658 & Nil \\
\hline Sucrose & Nil & 562 \\
\hline Casein & 188 & 188 \\
\hline Methionine & 1.9 & 1.9 \\
\hline Gelatin & 14.1 & 14.1 \\
\hline Safflower oil & 41.4 & 82.4 \\
\hline Bran & 37.6 & 37.6 \\
\hline Vitamin Mix ${ }^{a}$ & 9.4 & 9.4 \\
\hline Mineral Mix ${ }^{b}$ & 49.7 & 49.7 \\
\hline
\end{tabular}

${ }^{\mathrm{a}}$ Supplied per kilogram of vitamin mix: $3 \mathrm{~g}$ thiamine mononitrate, $3 \mathrm{~g}$ riboflavin, $3.5 \mathrm{~g}$ pyridoxine hydrochloride, $15 \mathrm{~g}$ nicotinamide, $8 \mathrm{~g}$ D-calcium pantothenate, $1 \mathrm{~g}$ folic acid, $0.1 \mathrm{~g}$ d-biotin, $5 \mathrm{mg}$ cyanocobalamine, $12.5 \mathrm{~g}$ cholecalciferol, $25 \mathrm{mg}$ acetomenaphthone, $600 \mathrm{mg}$ vitamin A acetate, $22 \mathrm{~g} \mathrm{~d}$-l $\alpha$-tocophenyl acetate and $10 \mathrm{~g}$ choline chloride.

${ }^{\mathrm{b}}$ Supplied per kilogram of mineral mix: $65.2 \mathrm{~g} \mathrm{NaCl}, 105.7 \mathrm{~g} \mathrm{KCl}, 200.2 \mathrm{~g} \mathrm{KH}_{2} \mathrm{PO}_{4}, 40.0 \mathrm{~g} \mathrm{FeCH}_{3} \mathrm{O}_{2} .5 \mathrm{H}_{2} \mathrm{O}, 512.4 \mathrm{~g} \mathrm{CaCO}, 0.8 \mathrm{~g}$ $\mathrm{KI}, 0.9 \mathrm{~g} \mathrm{NaF}, 1.4 \mathrm{~g} \mathrm{CuSO}_{4} .5 \mathrm{H}_{2} \mathrm{O}, 0.4 \mathrm{~g} \mathrm{MnSO}_{4}, 0.05 \mathrm{~g} \mathrm{CoNO}_{3}$ and addition of $\mathrm{MgSO}_{4} .7 \mathrm{H}_{2} \mathrm{O}$ to provide $507 \mathrm{mg}$ of $\mathrm{Mg}$.

\subsection{Plasma preparation and estimation of glucose}

At the start of the experiment and after every 4 weeks, animals were fasted overnight and blood samples were drawn by puncturing the orbital sinus of the animals under light anesthesia. Blood samples were drawn in vials containing anticoagulant namely potassium oxalate and sodium fluoride. Blood was centrifuged at $3000 \mathrm{~g}$ for 10 minutes. Plasma was aspirated and stored at $4^{\circ} \mathrm{C}$ till further use for various estimations except glucose, which was estimated immediately. Plasma glucose was measured using GOD/POD method by Trinder [20] (Enzopak kit).

\subsection{Analysis of Plasma lipid Profile}

Plasma total lipids were estimated by the method of Frings and Fendley [21], triglycerides by GPO-Trinder enzymatic method (PAP) of McGowan et al [22] (Erbamannheim kit), plasma Cholesterol by CHOD-PAP method of Roeschlau's [23] (Erbamannheim kit) and plasma HDL-Cholesterol by phosphotungstic method of Burstein [24] (Erbamannheim kit).

VLDL and LDL were calculated by the formulae of Friedwald et al [25] according to which
VLDL-Cholesterol $(\mathrm{mg} / \mathrm{dl})=$ Concentration of triglycerides $/ 5$

LDL-Cholesterol $(\mathrm{mg} / \mathrm{dl})=$ Total Cholesterol (VLDL + HDL)

\subsection{Analysis of tissue lipids}

At the end of the stipulated period of 12 weeks animals were sacrificed and liver and heart organs were removed. Liver and heart tissue lipids were extracted using the standard Folch [26] extraction technique. Tissue cholesterol was estimated by the method of Zlatkis et al [27], tissue triglycerides by the method of Van Handel and Zilversmith [28].

The method of Bartlett [29] was used for the determination of tissue phospholipids phosphorous. Total tissue lipids and tissue glycolipids were measured by the method of Fringes [21] and Dubois et al [30] respectively.

\subsection{Assay of plasma insulin}

Plasma insulin was assayed using double antibody radioimmunoassay technique of Berson and Yellow [31].

\subsection{Statistical Analysis}

Results were expressed as Mean \pm S.D. Statistical analyses was performed by using one๑) 2010 by NWPII. All rights reserved. $\quad 354$ 
way ANOVA followed by Fischer's least significance difference test. The statistical analysis was done using Jandel Sigma Stat Statistical
Software version 2.0. Statistical significance of the results were calculated at least at $\mathrm{p}<0.05$.

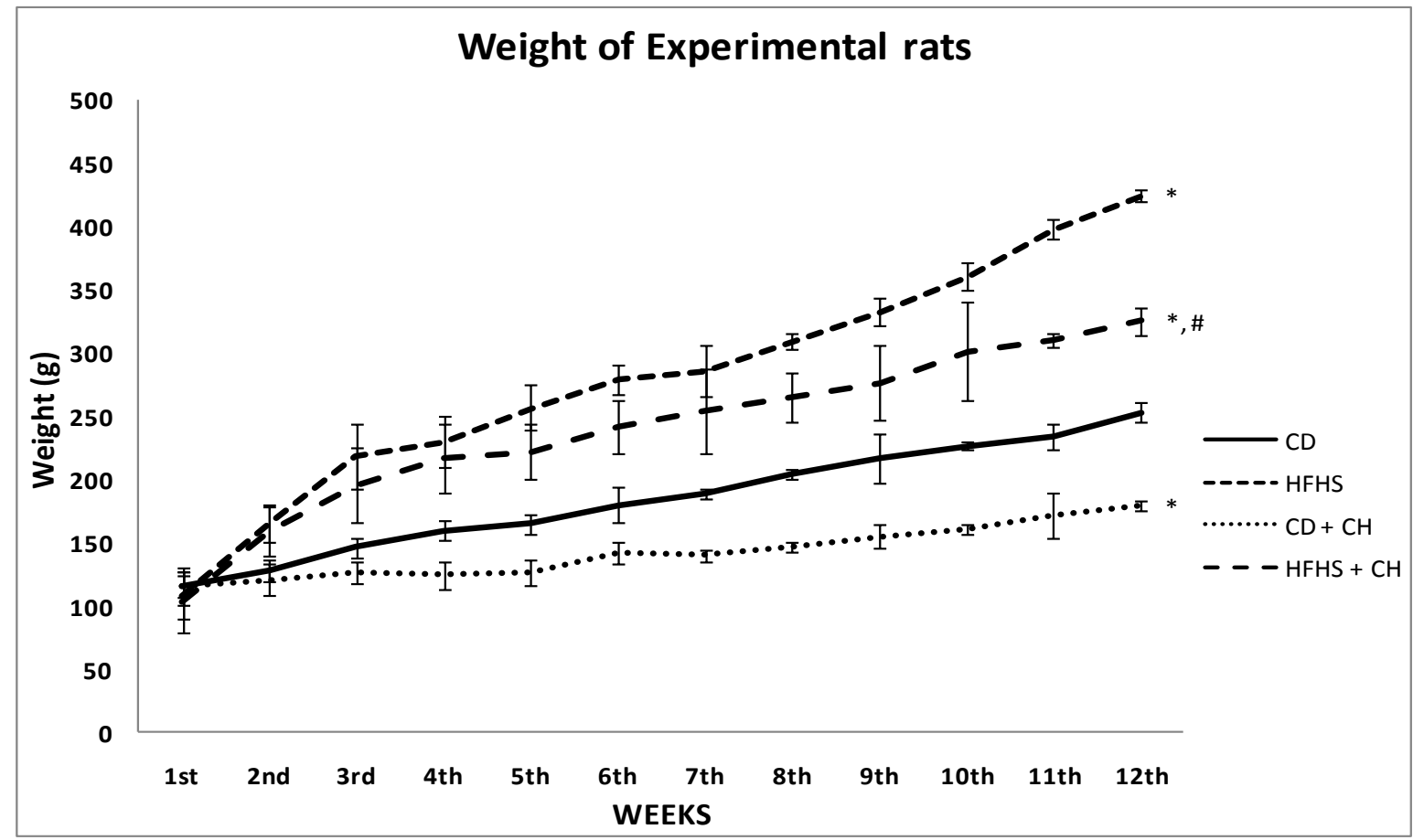

Figure 1. Weekly body weight gain of experimental animals. Values are mean \pm SD with 6 animals per group. ${ }^{*} \mathrm{p}<0.05$ vs. $\mathrm{CD} ;{ }^{\#} \mathrm{p}<0.05$ vs. HFHS.

\section{Results}

\subsection{Effect of (+)-catechin hydrate on the body weight gain and organ weight of control and high fat high sucrose diet fed rats}

Body weight gain was significantly affected in rats given (+)-catechin hydrate (Figure 1). In CD group, the body weight gain was $119 \%$ in 12 weeks, the increase in weight was only $55 \%$ in rats of $\mathrm{CD}+\mathrm{CH}$ group during the same period. In rats of HFHS group, the weight gain was $291 \%$ indicating high fat high sucrose induced obesity as compared to $\mathrm{CD}$ group. Body weight gain in $\mathrm{HFHS}+\mathrm{CH}$ group was $215 \%$ indicating that $(+)-$ catechin hydrate significantly prevented body weight gain of rats of this group compared to HFHS group $(\mathrm{p}<0.001)$.

Administration of (+)-catechin hydrate resulted in smaller increase in heart and liver weights and hence, attenuated hypertrophy in rats fed control diet as well as high fat and high sucrose diet (Table 2). Liver weight increased $8 \%$ less in $\mathrm{CD}+\mathrm{CH}$ group compared to the $\mathrm{CD}$ group $(\mathrm{p}<0.0001)$ and $6.3 \%$ less in HFHS $+\mathrm{CH}$ group compared to the HFHS group $(\mathrm{p}<0.0001)$. Heart tissue weight on the other hand increased $12 \%$ less in $\mathrm{CD}+\mathrm{CH}$ group compared to $\mathrm{CD}$ group $(\mathrm{p}<0.0001)$ and $14 \%$ less in HFHS $+\mathrm{CH}$ group as compared to the HFHS group ( $\mathrm{p}<0.001)$.

\subsection{Effect of (+)-catechin hydrate on the fasting plasma glucose levels}

The level of fasting plasma glucose was $10.2 \%$ less $(p<0.0001)$ in $\mathrm{CD}+\mathrm{CH}$ group at the end of 12th week as compared to CD group. Plasma glucose levels in HFHS group increased by $57 \%$ at the end of $12^{\text {th }}$ week compared to CD group ( $<<0.0001)$ (Table 3). However $(+)$-catechin hydrate caused $9.6 \%$ less increase in glucose 
levels in HFHS $+\mathrm{CH}$ group during $12^{\text {th }}$ week $(\mathrm{p}<0.0001)$.

\subsection{Effect of (+)-catechin hydrate on plasma total lipids}

The levels of plasma total lipids in $\mathrm{CD}+\mathrm{CH}$ group were 6\% ( $<<0.01), 7 \%(\mathrm{p}<0.001)$ and $10 \%$ $(\mathrm{p}<0.001)$ lower during $4^{\text {th }}, 8^{\text {th }}$ and $12^{\text {th }}$ week respectively compared to the $\mathrm{CD}$ group (Figure 2). However, these levels were significantly higher in HFHS group by $23 \%, 60 \%$ and $52 \%$ during $4^{\text {th }}$, $8^{\text {th }}$ and $12^{\text {th }}$ week respectively as compared to the $\mathrm{CD}$ group $(\mathrm{p}<0.0001$ in each case $)$ but significantly lower by $11 \%, 25 \%$ and $20 \%$ ( $<<0.001$ in each case) during $4^{\text {th }}, 8^{\text {th }}$ and $12^{\text {th }}$ week respectively in HFHS $+\mathrm{CH}$ group.

Table 2. Organ weight of experimental animals

\begin{tabular}{lllll}
\hline \multicolumn{5}{c}{ Organ weight of experimental animals (g) } \\
\hline ORGAN & $\begin{array}{l}\text { GROUP 1 } \\
\text { (CD) }\end{array}$ & $\begin{array}{l}\text { GROUP 2 } \\
\text { (CD + CH) }\end{array}$ & $\begin{array}{l}\text { GROUP 3 } \\
\text { (HFHS) }\end{array}$ & $\begin{array}{l}\text { GROUP 4 } \\
\text { (HFHS + CH) }\end{array}$ \\
\hline LIVER & $6.59 \pm 0.17$ & $6.06 \pm 0.05^{*}$ & $8.88 \pm 0.13^{*}$ & $8.32 \pm 0.14^{\#}$ \\
\hline HEART & $0.68 \pm 0.02$ & $0.60 \pm 0.02^{*}$ & $1.36 \pm 0.09^{*}$ & $1.17 \pm 0.05^{\#}$ \\
\hline
\end{tabular}

Values are mean \pm SD with 6 animals per group. $* \mathrm{p}<0.05$ vs. $\mathrm{CD} ;{ }^{\#} \mathrm{p}<0.05$ vs. HFHS.

Table 3. Levels of fasting plasma glucose in experimental rats.

Plasma glucose levels (mg/dl)

\begin{tabular}{lllll}
\hline & $\begin{array}{l}\text { GROUP 1 } \\
\text { (CD) }\end{array}$ & $\begin{array}{l}\text { GROUP 2 } \\
\text { (CD + CH) }\end{array}$ & GROUP 3 (HFHS) & $\begin{array}{l}\text { GROUP 4 } \\
\text { (HFHS + CH }\end{array}$ \\
\hline START & $99.13 \pm 5.97$ & $95.11 \pm 6.27$ & $98.09 \pm 11.25$ & $97.54 \pm 11.67$ \\
\hline 4 WEEKS & $94.86 \pm 0.78$ & $93.91 \pm 0.65^{*}$ & $128.47 \pm 3.91^{*}$ & $113.87 \pm 6.44^{\#}$ \\
\hline 8WEEKS & $96.43 \pm 10.08$ & $90.86 \pm 4.10^{\text {NS1 }}$ & $155.51 \pm 23.44^{*}$ & $126.08 \pm 17.04^{\#}$ \\
\hline 12WEEKS & $93.89 \pm 1.17$ & $84.32 \pm 3.37^{*}$ & $148.02 \pm 10.36^{*}$ & $133.75 \pm 7.96^{\#}$ \\
\hline
\end{tabular}

Values are mean \pm SD with 6 animals per group. $* \mathrm{p}<0.05$ vs. CD during same week; ${ }^{\#} \mathrm{p}<0.05$ vs. HFHS during same week; ${ }^{\mathrm{NS} 1}$ non-significant change vs. CD during same week.

\subsection{Effect of (+)-catechin hydrate on the plasma Triglyceride levels}

As shown in figure 3, (+)-catechin hydrate administration significantly decreased plasma triglycerides in $\mathrm{CD}+\mathrm{CH}$ group compared to $\mathrm{CD}$ group during the $4^{\text {th }}, 8^{\text {th }} \& 12^{\text {th }}$ week period by $40 \%, 30 \%$ and $12.5 \%$ respectively $(\mathrm{p}<0.001$ in each case). In HFHS group, the plasma triglyceride levels showed a marked elevation of $52 \%, 172 \%$ and $143 \%$ during $4^{\text {th }}, 8^{\text {th }}$ and $12^{\text {th }}$ week compared to $\mathrm{CD}$ group $(\mathrm{p}<0.0001$ in each case). Administration of (+)-catechin hydrate in HFHS $+\mathrm{CH}$ group significantly lowered plasma triglyceride levels during $4^{\text {th }}(\mathrm{p}<0.05), 8^{\text {th }}$ $(\mathrm{p}=0.001)$ and $12^{\text {th }}$ week $(\mathrm{p}<0.01)$ period compared to the HFHS group during which the levels were found to be $49.07 \pm 7.36,63.6 \pm 22.53 \& 65.92 \pm$ $14.81 \mathrm{mg} / \mathrm{dl}$ respectively.

\subsection{Effect of (+)-catechin hydrate on the plasma cholesterol levels}

In $\mathrm{CD}+\mathrm{CH}$ group there was significant reduction in cholesterol levels during $12^{\text {th }}$ week only compared to $\mathrm{CD}$ group $(\mathrm{p}<0.0001)$ (Figure 4). Cholesterol levels increased by $39.5 \%$ in HFHS group during 12 weeks as compared to $C D$ group $(\mathrm{p}<0.0001)$. In $\mathrm{HFHS}+\mathrm{CH}$ group cholesterol levels showed non-significant change till 4 week period but the levels were significantly lower during $8^{\text {th }}$ and $12^{\text {th }}$ week by $12 \%(\mathrm{p}<0.05)$ and $7 \%(\mathrm{p}<0.05)$ respectively as compared to HFHS group. 


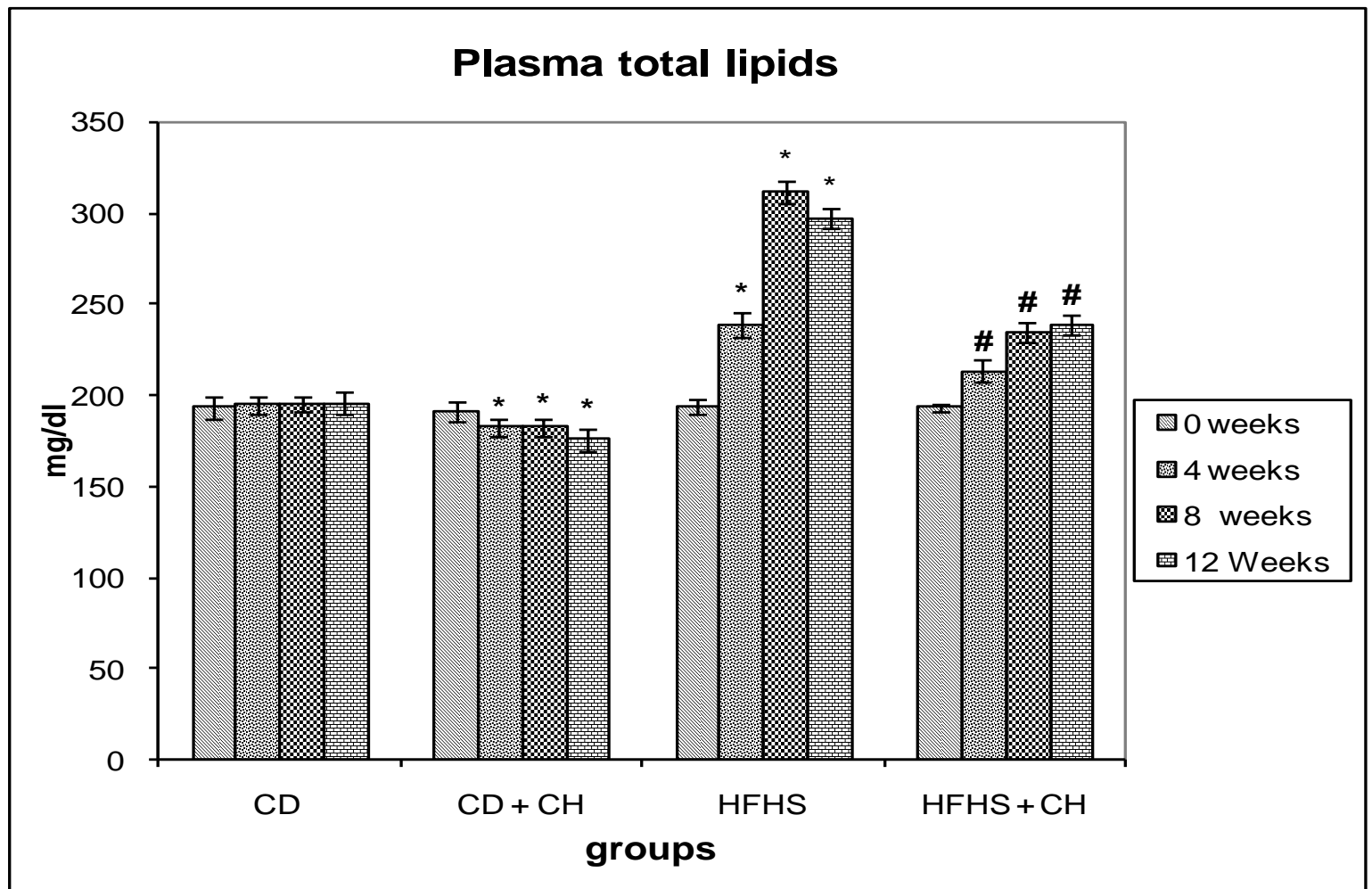

Figure 2. Effect of (+)-catechin hydrate on plasma total lipid levels in control diet fed and high fat high sucrose diet fed animals. Values are mean \pm SD with 6 animals per group. ${ }^{*} \mathrm{p}<0.05$ vs. CD during same week; ${ }^{\#} \mathrm{p}<0.05$ vs. HFHS during same week.

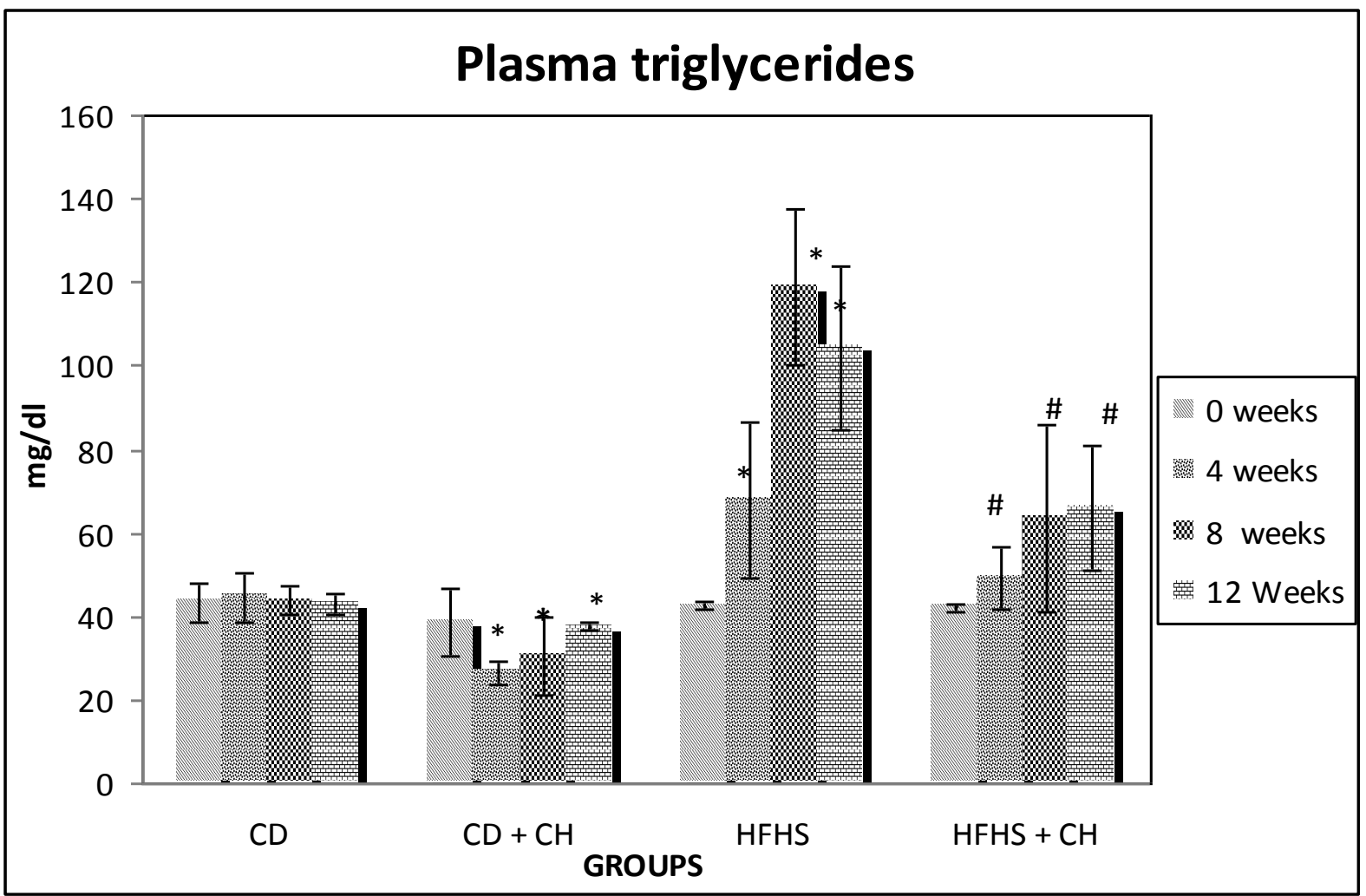

Figure 3. Effect of (+)-catechin hydrate on plasma triglyceride levels in control diet fed and high fat high sucrose diet fed animals. Values are mean \pm SD with 6 animals per group. ${ }^{*} \mathrm{p}<0.05$ vs. CD during same week; ${ }^{\#} \mathrm{p}<0.05$ vs. HFHS during same week.

Am. J. Biomed. Sci. 2010, 2(4), 352-364; doi: 10.5099/aj100400352 @ 2010 by NWPII. All rights reserved. 


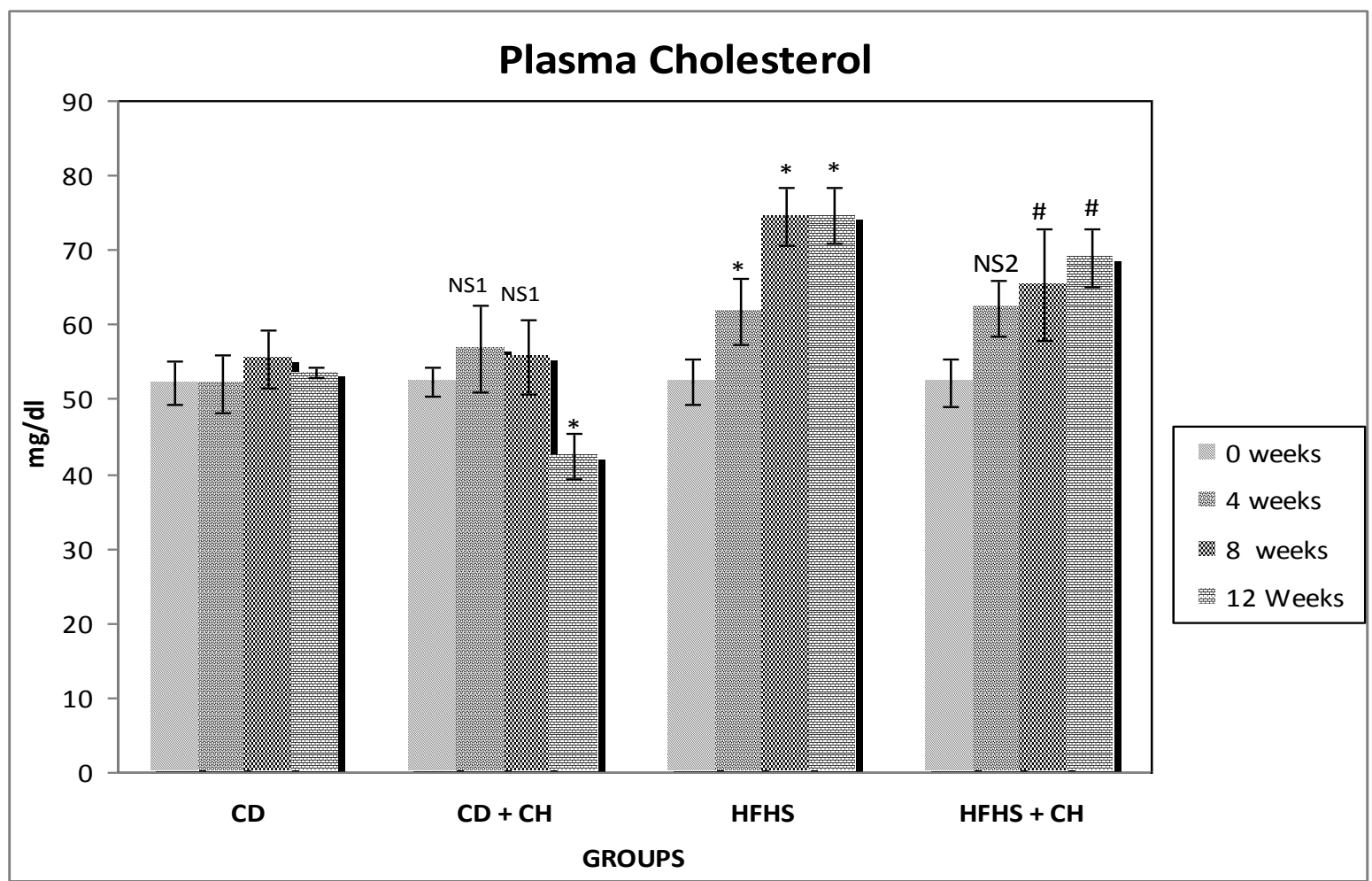

Figure 4. Effect of (+)-catechin hydrate on plasma cholesterol levels in control diet fed and high fat high sucrose diet fed animals. Values are mean \pm SD with 6 animals per group. ${ }^{*} \mathrm{p}<0.05$ vs. CD during same week; ${ }^{*} \mathrm{p}<0.05$ vs. HFHS during same week; ${ }^{N S 1}$ non-significant change vs. CD during same week; ${ }^{\text {NS2 }}$ non-siginicant change vs. HFHS during same week.

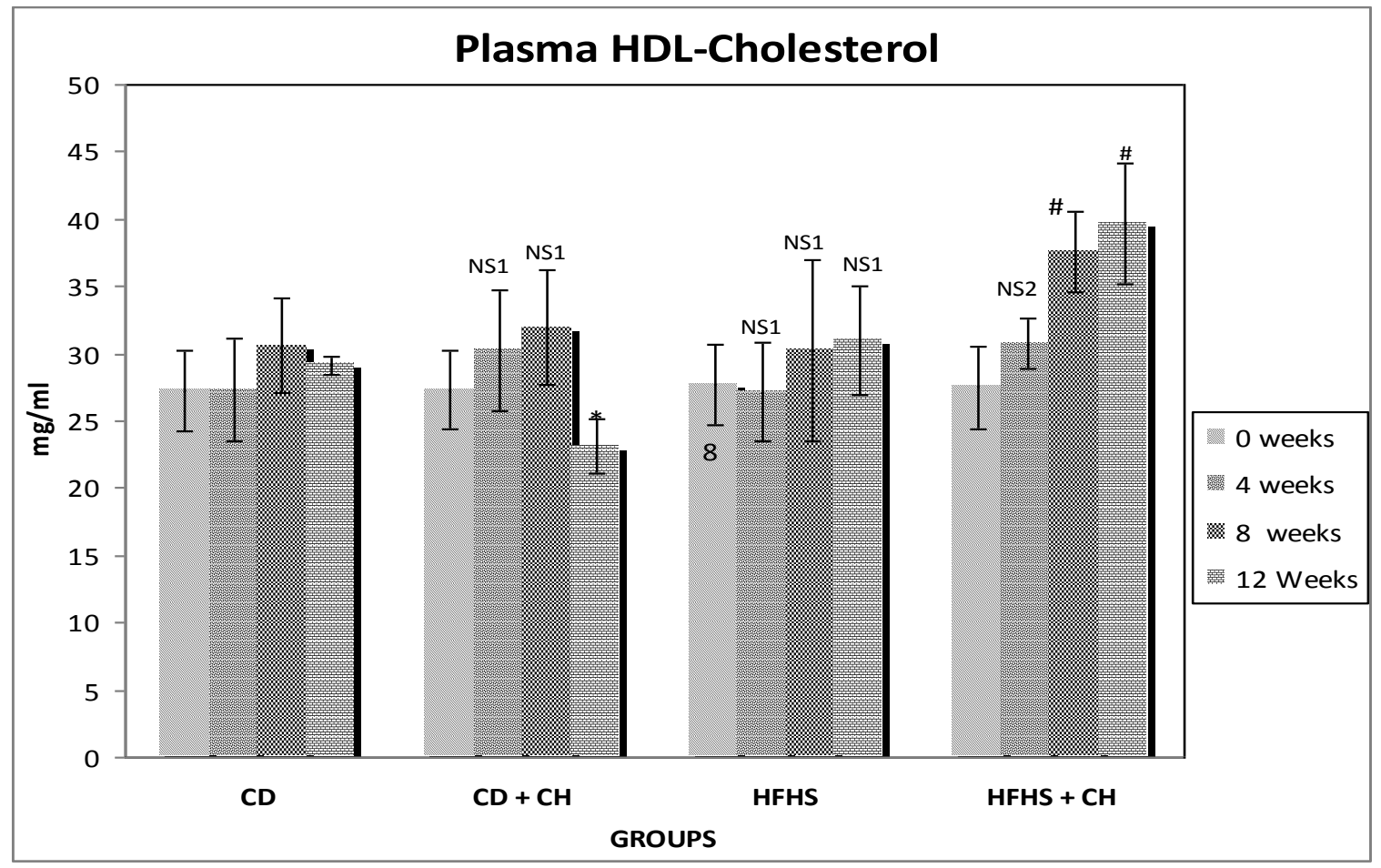

Figure 5. Effect of (+)-catechin hydrate on plasma HDL-Cholesterol levels in control diet fed and high fat high sucrose diet fed animals. Values are mean \pm SD with 6 animals per group. ${ }^{*} \mathrm{p}<0.05$ vs. CD during same week; ${ }^{\#}<<0.05$ vs. HFHS during same week; ${ }^{\mathrm{NS} 1}$ non-significant change vs. CD during same week; ${ }^{\mathrm{NS} 2}$ non-siginicant change vs. HFHS during same week.

Am. J. Biomed. Sci. 2010, 2(4), 352-364; doi: 10.5099/aj100400352 @ 2010 by NWPII. All rights reserved. 
3.6 Effect of (+)-catechin hydrate on plasma HDL-cholesterol, VLDL-Cholesterol and LDL Cholesterol

Administration of (+)-catechin hydrate caused significant reduction of $20 \%(\mathrm{p}<0.0001)$ during $12^{\text {th }}$ week only compared to the CD group (Figure 5). Though HDL-cholesterol levels remained unaffected in HFHS group compared to CD group, these levels significantly increased by $24.5 \%$ $(\mathrm{p}<0.01)$ and $28 \%(\mathrm{p}<0.01)$ in HFHS $+\mathrm{CH}$ group during $8^{\text {th }}$ and $12^{\text {th }}$ week respectively. During $12^{\text {th }}$ week VLDL-Cholesterol levels were $12.6 \%$ lower $(\mathrm{p}<0.001)$ and LDL-Cholesterol levels were $25 \%$ lower $(\mathrm{p}<0.001)$ as compared to $\mathrm{CD}$ group (Table 4 and 5). Both VLDL and LDL Cholesterol levels increased in HFHS group during $12^{\text {th }}$ week ( $p<0.0001$ in each case) as compared to the CD group. Administration of (+)-catechin hydrate in HFHS + CH group significantly decreased VLDLCholesterol and LDL-Cholesterol during $8^{\text {th }}$ and $12^{\text {th }}$ week $(\mathrm{p}<0.01)$.

Table 4. Plasma VLDL-cholesterol levels in experimental animals

\begin{tabular}{lllll}
\hline \multicolumn{4}{c}{ Plasma VLDL-Cholesterol (mg/dl) } \\
\hline & $\begin{array}{l}\text { GROUP 1 } \\
\text { (CD) }\end{array}$ & $\begin{array}{l}\text { GROUP 3 } \\
\text { (CD + CH) }\end{array}$ & $\begin{array}{l}\text { GROUP 2 } \\
\text { (HFHS) }\end{array}$ & $\begin{array}{l}\text { GROUP 4 } \\
\text { (HFHS + CH) }\end{array}$ \\
\hline 0 weeks & $8.74 \pm 0.58$ & $8.72 \pm 0.52$ & $8.88 \pm 0.53$ & $8.67 \pm 1.10$ \\
4 weeks & $8.92 \pm 1.19$ & $5.30 \pm 0.53^{*}$ & $13.58 \pm 3.69^{*}$ & $9.81 \pm 1.97^{\text {NS2 }}$ \\
8weeks & $8.74 \pm 0.52$ & $8.08 \pm 1.86^{\mathrm{NS} 1}$ & $23.78 \pm 3.93^{*}$ & $12.79 \pm 4.51^{\#}$ \\
12weeks & $8.62 \pm 0.36$ & $7.53 \pm 0.34^{*}$ & $20.88 \pm 4.42^{*}$ & $13.18 \pm 2.96^{\#}$
\end{tabular}

Values are mean \pm SD with 6 animals per group. ${ }^{*} \mathrm{p}<0.05$ vs. CD during same week; ${ }^{\#} \mathrm{p}<0.05$ vs. HFHS during same week; ${ }^{\text {NS1 }}$ nonsignificant change vs. CD during same week; ${ }^{\text {NS2 }}$ non-siginicant change vs. HFHS during same week.

Table 5. Plasma LDL-Cholesterol levels in experimental animals

\begin{tabular}{lllll}
\hline \multicolumn{4}{c}{ Plasma LDL-cholesterol (mg/d) } \\
\hline & $\begin{array}{l}\text { GROUP 1 } \\
\text { (CD) }\end{array}$ & $\begin{array}{l}\text { GROUP 3 } \\
\text { (CD + CH) }\end{array}$ & $\begin{array}{l}\text { GROUP 2 } \\
\text { (HFHS) }\end{array}$ & $\begin{array}{l}\text { GROUP 4 } \\
\text { (HFHS + CH) }\end{array}$ \\
\hline 0 weeks & $15.78 \pm 0.72$ & $15.82 \pm 1.38$ & $15.72 \pm 1.18$ & $15.90 \pm 1.40$ \\
4 weeks & $15.88 \pm 1.69$ & $21.22 \pm 1.34^{*}$ & $20.99 \pm 1.66^{*}$ & $21.62 \pm 1.08^{\text {NS2 }}$ \\
8weeks & $16.30 \pm 1.69$ & $15.53 \pm 1.67^{\text {NS1 }}$ & $20.60 \pm 2.48^{*}$ & $14.98 \pm 2.24^{\#}$ \\
12weeks & $15.72 \pm 0.76$ & $11.80 \pm 1.60^{*}$ & $21.45 \pm 1.15^{*}$ & $16.07 \pm 1.28^{\#}$ \\
\hline
\end{tabular}

Values are mean \pm SD with 6 animals per group. ${ }^{*} \mathrm{p}<0.05$ vs. CD during same week; ${ }^{*} \mathrm{p}<0.05$ vs. HFHS during same week; ${ }^{\mathrm{NS} 1}$ nonsignificant change vs. CD during same week; ${ }^{\mathrm{NS} 2}$ non-siginicant change vs. HFHS during same week.

Table 6. Content of tissue lipids in the liver homogenate ( $\mathrm{mg} / \mathrm{g}$ liver tissue)

\begin{tabular}{lllll}
\hline & $\begin{array}{l}\text { GROUP1 } \\
(\mathrm{CD})\end{array}$ & $\begin{array}{l}\text { GROUP2 } \\
(\mathrm{CD}+\mathrm{CH})\end{array}$ & $\begin{array}{l}\text { GROUP3 } \\
(\mathrm{HFHS})\end{array}$ & $\begin{array}{l}\text { GROUP4 } \\
(\mathrm{HFHS}+\mathrm{CH})\end{array}$ \\
\hline Total lipids & $45.5 \pm 2.05$ & $39.5 \pm 1.75^{*}$ & $52.77 \pm 3.10^{*}$ & $47.61 \pm 1.54^{\#}$ \\
\hline Phospholipids & $26.08 \pm 0.97$ & $24.38 \pm 0.88^{*}$ & $27.81 \pm 0.86^{\mathrm{NS1}}$ & $25.31 \pm 1.17^{\#}$ \\
\hline Cholesterol & $2.62 \pm 0.07$ & $2.17 \pm 0.13^{*}$ & $2.82 \pm 0.06^{*}$ & $2.55 \pm 0.11^{\#}$ \\
\hline Triglycerides & $8.18 \pm 0.62$ & $7.85 \pm 0.72^{\mathrm{NS1}}$ & $21.55 \pm 2.95^{*}$ & $14.91 \pm 0.87^{\#}$ \\
\hline Glycolipids & $4.31 \pm 0.09$ & $2.32 \pm 0.24^{*}$ & $4.86 \pm 0.12^{*}$ & $3.94 \pm 0.09^{\#}$
\end{tabular}

Values are mean \pm SD with 6 animals per group. ${ }^{*} \mathrm{p}<0.05$ vs. CD during same week; ${ }^{*} \mathrm{p}<0.05$ vs. HFHS during same ${ }^{\text {week; }}{ }^{\mathrm{NS} 1}$ nonsignificant change vs. CD during same week. 


\subsection{Effect of (+)-catechin hydrate on plasma insulin levels}

In $\mathrm{CD}+\mathrm{CH}$ group, plasma insulin was significantly lower than the $\mathrm{CD}$ group during the $4^{\text {th }}$ week (Figure 6). In HFHS group plasma insulin levels were found to be significantly higher than the $C D$ group $(p<0.0001)$ after 4 weeks. Administration of (+)-catechin hydrate in HFHS + $\mathrm{CH}$ group significantly lowered the plasma insulin levels during the $8^{\text {th }}$ and $12^{\text {th }}$ week by $14 \%$ and $26.5 \%$ as compared of HFHS group ( $<<0.0001$ in each case).

\subsection{Effect of (+)-catechin hydrate on tissue lipids}

In liver of HFHS group, total lipids increased by $15.98 \% \quad(p<0.01)$, cholesterol by $7.6 \%$ $(\mathrm{p}<0.001)$, triglycerides by $163.45 \%(\mathrm{p}<0.0001)$ and glycolipids by $12.76 \%$ compared to $\mathrm{CD}$ group while phospholipids showed non-significant change (Table 6). (+)-catechin hydrate decreased total lipid levels by $13.2 \%$ in $\mathrm{CD}+\mathrm{CH}$ group compared to $\mathrm{CD}$ group $(\mathrm{p}<0.001)$ and $9.8 \%$ in HFHS + CH group compared to the HFHS group ( $\mathrm{p}<0.01$ ). Phospholipid content in $\mathrm{CD}+\mathrm{CH}$ group was $6.5 \%$ lower than $\mathrm{CD}$ group $(\mathrm{p}<0.01)$ and $9 \%$ lower in HFHS $+\mathrm{CH}$ group compared to HFHS group $(\mathrm{p}<0.01) . \quad(+)$-catechin hydrate also significantly decreased liver cholesterol in both $\mathrm{CD}+\mathrm{CH}$ and HFHS + $\mathrm{CH}$ group by $17 \%$ ( $\mathrm{p}<$ $0.0001)$ and $9.5 \%(p<0.01)$ as compared to the $C D$ and HFHS group respectively. Though liver triglycerides showed non-significant change in $\mathrm{CD}$ $+\mathrm{CH}$ group, there was significant $30 \%$ reduction in HFHS + CH group compared to the HFHS group $(\mathrm{p}<0.01) .(+)$-catechin hydrate also inhibited the accumulation of liver glycolipids by $46.17 \%$ in $\mathrm{CD}+\mathrm{CH}$ group and $18.93 \%$ in $\mathrm{HFHS}+\mathrm{CH}$ group compared to the $\mathrm{CD}$ and HFHS group respectively.

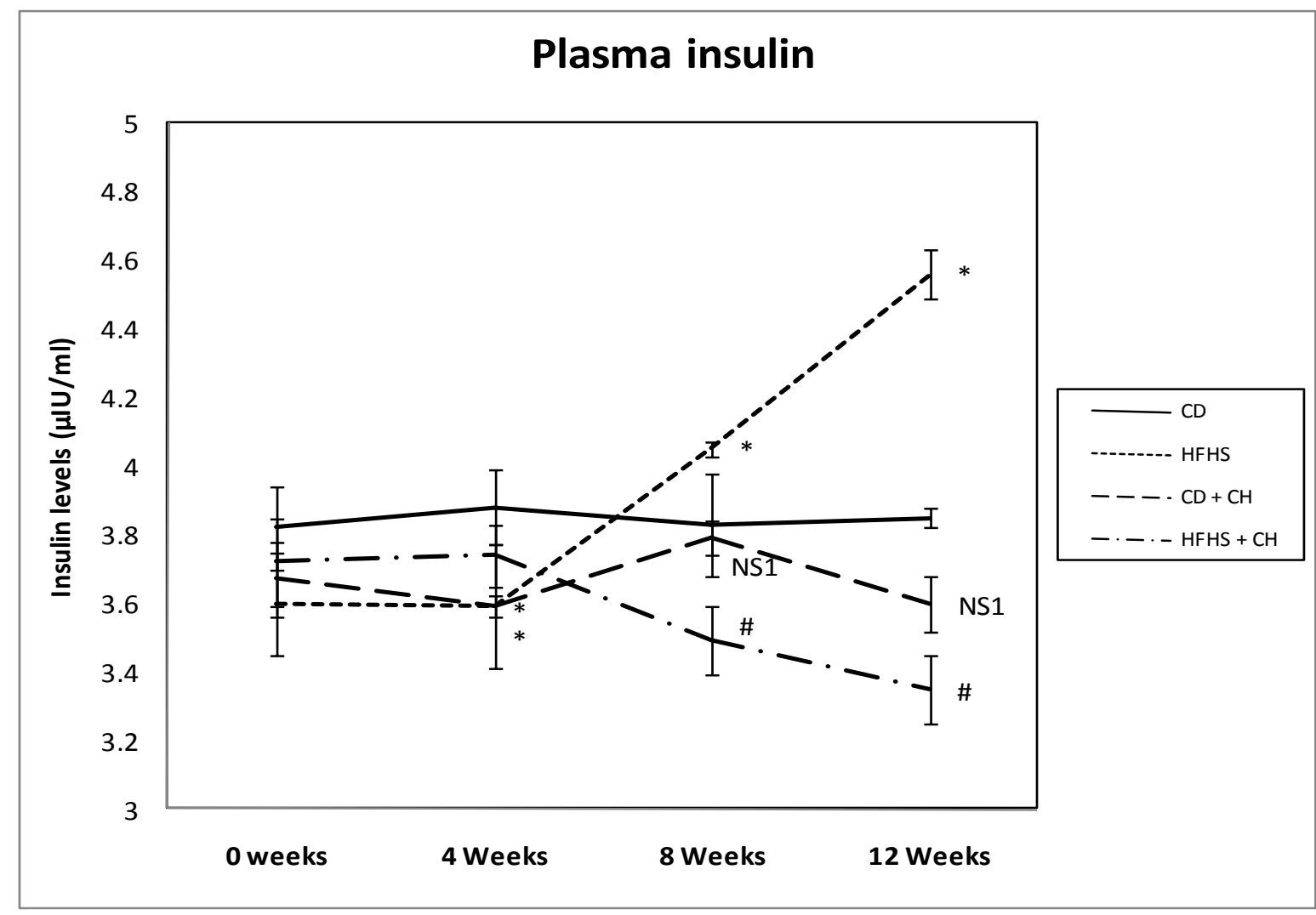

Figure 6. Levels of plasma insulin in experimental animals. Values are mean \pm SD with 6 animals per group. $* p<0.05$ vs. CD during same week; ${ }^{\#}$ < $<0.05$ vs. HFHS during same week; ${ }^{N S 1}$ non-significant change vs. CD during same week. 
In heart of HFHS group, total lipids rose by $26.43 \% \quad(\mathrm{p}<0.0001)$, cholesterol by $15.64 \%$ $(\mathrm{p}<0.001)$ and glycolipids by $15.92 \%(\mathrm{p}<0.0001)$ compared to $\mathrm{CD}$ group while phospholipids and Triglycerides showed a non-significant change (Table 7). Supplementation of (+)-catechin hydrate significantly reduced heart total lipids and cholesterol content only in $\mathrm{CD}+\mathrm{CH}$ group by $6.83 \%$ and $5.21 \%$ compared to the $\mathrm{CD}$ group $(\mathrm{p}<0.01$ in each case). (+)-catechin hydrate supplementation decreased Triglyceride content in both $\mathrm{CD}+\mathrm{CH}$ as well as HFHS $+\mathrm{CH}$ group by $29.97 \%$ and $14.64 \%$ compared to $\mathrm{CD}$ and HFHS group respectively ( $\mathrm{p}<0.01$ in each case). In HFHS $+\mathrm{CH}$ group, the decrease in glycolipid content was $34.33 \%$ and significantly different from the HFHS group $(\mathrm{p}<0.0001)$.

Table 7. Content of tissue lipids in the heart homogenate ( $\mathrm{mg} / \mathrm{g}$ heart tissue)

\begin{tabular}{lllll}
\hline & $\begin{array}{l}\text { GROUP1 } \\
(\mathrm{CD})\end{array}$ & $\begin{array}{l}\text { GROUP2 } \\
(\mathrm{CD}+\mathrm{CH})\end{array}$ & $\begin{array}{l}\text { GROUP3 } \\
(\mathrm{HFHS})\end{array}$ & $\begin{array}{l}\text { GROUP4 } \\
(\mathrm{HFHS}+\mathrm{CH})\end{array}$ \\
\hline Total lipids & $28.53 \pm 1.03$ & $26.58 \pm 0.96^{*}$ & $36.07 \pm 2.38^{*}$ & $35.19 \pm 2.13^{\mathrm{NS} 2}$ \\
\hline Phospholipids & $14.52 \pm 0.66$ & $13.81 \pm 1.05^{\mathrm{NS} 1}$ & $13.28 \pm 1.98^{\mathrm{NS} 1}$ & $12.17 \pm 1.04^{\mathrm{NS} 2}$ \\
\hline Cholesterol & $2.11 \pm 0.10$ & $2.00 \pm 0.09^{*}$ & $2.44 \pm 0.15^{*}$ & $2.30 \pm 0.09^{\mathrm{NS} 2}$ \\
\hline Triglycerides & $13.48 \pm 0.87$ & $9.44 \pm 0.50^{*}$ & $13.25 \pm 1.27^{\mathrm{NS} 1}$ & $11.31 \pm 0.62^{\#}$ \\
\hline Glycolipids & $4.02 \pm 0.12$ & $4.29 \pm 0.38^{\mathrm{NS} 1}$ & $4.66 \pm 0.21^{*}$ & $3.06 \pm 0.12^{\#}$
\end{tabular}

Values are mean \pm SD with 6 animals per group. ${ }^{*} \mathrm{p}<0.05$ vs. CD during same week; ${ }^{\#} \mathrm{p}<0.05$ vs. HFHS during same week;

${ }^{\mathrm{NS} 1}$ non-significant change vs. CD during same week; ${ }^{\mathrm{NS} 2}$ non-siginicant change vs. HFHS during same week.

\section{Discussion}

This study clearly shows that high fat and high sucrose diet produces an obese insulin resistant type 2 diabetes model as the results show that even when there is hyperinsulinemia in HFHS group, there is concomitant hyperglycemia. We have previously shown that high sucrose diet given to $\mathrm{Mg}^{2+}$ deficient rats produce type 2 diabetes like condition [1, 32, 33]. Increased triglyceride level is a hallmark of type 2 diabetes which is very clear from the results of this study as triglyceride levels are very high in HFHS group as compared to CD group.

The results of the study show that (+)catechin hydrate decreases body weight gain in both $\mathrm{CD}+\mathrm{CH}$ and HFHS + $\mathrm{CH}$ groups. Dullo et $a l$ have shown that green tea catechins stimulated $\mathrm{O}_{2}$ consumption and energy expenditure in humans which may be the prime reason for the decrease of weight [34]. They also showed that these compounds are associated with sympathetic stimulation of fat oxidation as these inhibit the activity of Catechol-O-methyl transferase (the enzyme that degrades noradrenaline). Murase et al have shown that tea catechins in a dose dependent manner decrease body weight in rats [35]. Comparing decrease in body weight gain in $\mathrm{CD}+$ $\mathrm{CH}$ and $\mathrm{HFHS}+\mathrm{CH}$ groups reveal that (+)catechin hydrate has deleterious effect on rats of $\mathrm{CD}+\mathrm{CH}$ group as body weight gain was less than halved as compared to $\mathrm{CD}$ group making rats lean and weak. (+)-catechin hydrate had more effect in reducing heart weight gain than liver weight gain in both $\mathrm{CD}+\mathrm{CH}$ and HFHS $+\mathrm{CH}$ group.

The study further shows that administration of (+)-catechin hydrate had a beneficial effect on insulin sensitivity of high fat high sucrose fed rats as the glucose levels were found to be consistently lower in HFHS $+\mathrm{CH}$ group as compared to the HFHS group. Reports in literature have shown green tea extract has anti diabetic effects in rats $[36,37]$. In vitro studies have shown that EGCG, has the capacity to decrease glucose production in H4IIE rat hepatoma cells [38].

Previous studies have shown that dietary sucrose supplementation increases gene expression of several enzymes including acetylcoenzyme A carboxylase and fatty acid synthase which lead to increase in triglyceride concentration in blood [39]. Green tea consumption has been associated with decreased 
serum levels of triglycerides [40]. Studies have shown that jasmine green tea epicatechins are hypolipidemic in hamsters fed a high fat diet and their hypolipidemic effect is due to decreased intestinal absorption of dietary lipids [41]. In the present study $(+)$-catechin hydrate also showed its hypolipidemic effect by significantly lowering plasma triglycerides during $4^{\text {th }}, 8^{\text {th }}$ and $12^{\text {th }}$ week.

(+)-catechin hydrate decreases the ratio of very low and low density lipoprotein cholesterol concentrations to high density lipoproteins concentrations. This is very important indication of the role (+)-catechin hydrate plays in preventing atherosclerosis and cardiovascular diseases. Thus our study showed a close association between consumption of $(+)$-catechin hydrate and normalization of plasma parameters which reflect cardiovascular diseases.

Previous studies have shown that green tea extract has insulin like effect [42]. Anderson et al have shown that EGCG can potentiate in vitro insulin activity [43]. Infact epigallocatechin gallate is regarded to have a modulating effect on the endocrine system and it is found to have improving effects on diabetes [44]. In our study persistent hyperinsulinemia which was found in rats fed high fat and high sucrose diet was improved by the administration of (+)-catechin hydrate.

\section{Conclusion}

The present study clearly shows that high fat and high sucrose diet produces an obese rat model which is hyperglycemic and hyperlipidemic and (+)-catechin hydrate is beneficial to some extent in reducing obesity and in improving plasma parameters.

\section{Acknowledgement}

The authors are grateful to the Council of Scientific and Industrial Research (CSIR), New Delhi, India, for providing fellowship to carry out this research work.

\section{References}

1 Chaudhary, D.P.; Boparai, R.K.; Sharma, R.; Bansal, D.D. Studies on the development of an insulin resistant rat model by chronic feeding of low magnesium high sucrose diet, Magnes Res, 2004, 17(4), 293-300.

2 Oliveros, L.; Calleigari, E.; Gimenez, M.S. Effects of sucrose fed on glucose tolerance and their relationship with lipid metabolism in maternal and foetal livers of rat, Arc. Physio Biochem, 1997, 105, 640-644.

3 Selvin, E. Gycemia (haemoglobin A1c) and incidence ischaemic stroke: the atherosclerosis risk in communities (ARIC) study, Lancet Neuro, 2005, 4, 821-826.

4 Cherubini, A. The VASA study group. High vitamin E plasma levels and low low density lipoprotein oxidation are associated with the absence of atherosclerosis in octogenarians, $J \mathrm{Am}$ Geriatr Soc, 2001, 49, 651-654.

5 Balentine, D.A.; Wiseman S.A.; Bouwens L.C. The chemistry of tea flavinoids, Crit Rev Food Sci Nutr, 1997, 37, 693-704.

6 Imai, K.; Nakachi, K. Cross-sectional study of effects of drinking green tea on cardiovascular and liver diseases, Br Med J, 1995, 310, 693-696.

7 Kono, S.; Shinchi, K.; Wakabayashi, K.; Honjo, S.; Todoroki, I.; Sakurai, Y.; Imanishi, K.; Nishikawa, H.; Ogawa, S.; Katsurada, M. Relation of green tea consumption to serum lipids and lipoproteins in Japanese men, J Epidemiol, 1996, 6, 128-133.

8 Fukuyo, M.; Hara, Y.; Muramatsu, K. Effects of tea leaf catechin (-)-epigallocatechin gallate on plasma cholesterol levels in rats, Nippon Eliyo Shokuryon Gakkaishi, 1986, 39, 495-500.

9 Sabu M.C, Smitha, K.; Ramadasan, K. Antidiabetic activity of green tea polyphenols and their role in reducing oxidative stress in experimental diabetes, J Ethnopharm, 2002, 83, 109-116.

10 Wolfram, S.; Raderstorff, D.; Preller, M.; Wang, Y.; Teixeria, S.R.; Riegger, C.; Weber, P. Epigallocatechin gallate supplementation alleviates diabetes in rodent, $J$ Nutr, 2006, 136, 2512-2518.

11 Wu, L.Y.; Juan, C.C.; Ho, L.T.; Hsu, Y.P.; Hwang, L.S. Effect of green tea supplementation on insulin sensitivity in Sprague-Dawley rats, J Agric Food Chem, 2004, 52, 643-648.

12 Kobayashi, Y.; Suzuki, M.; Satsu, H.; Arai, S.; Hara, Y.; Suzuki, K.; Miyamaoto, Y.; Shimizu, M. Green tea polyphenols inhibit the sodiumdependent glucose transporter of intestinal 
epithelial cells by a competitive mechanism, $J$ Agric Food Chem, 2000, 48, 5618-5623.

13 Dona, M.; Dell'Aica, I.; Calabrese, F.; Benelli, R.; Morini, M.; Albini, A.; Garbisa, S. Neutrophil restraint by green tea: inhibition of inflammation associated angiogenesis, and pulmonary fibrosis, $J$ Immunol, 2003, 170, 4335-41.

14 Osada, K.; Takahashi, M.; Hoshina, S.; Nakamura, M.; Nakamura, S.; Sugano, M. Tea catechins inhibit cholesterol oxidation accompanying oxidation of low density lipoproteins in vitro, Comp Biochem Physiol Part C Toxicol Pharmocol, 2001, 128, 153-64.

15 Kavanagh, K.T.; Hafer, L.J.; Kim, D.W.; Mann, K.K.; Sher, D.H.; Rogers, A.E.; Sonenshein, G.E. Green tea extracts decrease carcinogen induced mammary tumor burden in rats and rate o0f breaselt cancer cell proliferation in culture, $J$ Cell Biochem, 2001, 82, 387-98.

16 Weinreb, O.; Mandel, S.; Amit, T.; Youdin, M.B. Neurological mechanisms of green tea polyphenols in Alzheimer's and Parkinson's diseases, J Nutr Biochem, 2004, 15, 506-16.

17 Chisaka, T.; Matsuda, H.; Kubomura, Y.; Mochizuki, M.; Yamahara, J.; Fujimura, H. The effect of crude drugs on experimental hypercholesteremia: mode of action of (-)epigallocatechin gallate in tea leaves, Chem Phar Bull, 1988, 36(1), 227-233.

18 Wang, S.; Noh, S.K.; Koo, S.I. Epigallocatechin gallate and caffeine differentially inhibit the intestinal absorption of cholesterol and fat in ovariectomized rats, $J$ Nutr, 2006, 136(11), 27912796.

19 Brown, M.S.; Goldstein, J.L. A receptor-mediated pathway for cholesterol homeostasis, Science, 1986, 232(4746), 34-47.

20 Trinder, P. Determination of glucose in blood using glucose oxidase with an alternative oxygen acceptor, Ann Clin Biochem, 1969, 6, 24-25.

21 Frings, C.S.; Fendley, T.W.; Dunn, R.T.; Queen, C.A. Improved determination of total serum lipids by the sulfo phosphor-vanillin reaction, Clin Chem, 1972, 18, 673-674.

22 McGowan, MW.; Artiss J.D.; Strandbergh, D.R.; Zak, B. A peroxide-coupled method for the calorimetric determination of serum triglycerides, Clin Chem, 1983, 29, 538-542.

23 Roeschlav, P.; Bernt, E.; Griber W.A. Determination of total cholesterol in serum, Clin Chem Clin Biochem 1974, 12, 403-407.

24 Bustein, M.; Scholnick, H.R.; Morfin, R. Rapid method for the isolation of lipoproteins from human serum by precipitation with polyanions, $J$ Lipid Res, 1970, 11, 583-595.

25 Friedewald, W.T.; Levy, R.I.; Friedrickson, D.S. Estimation of concentration of LDL in cholesterol without the use of ultracentrifuge, Clin ChemI, 1972, 18, 499-502.

26 Folch, J.; Lees, M.; Sloane Stanley, G.H. A simple method for the isolation and purification of total lipids from animal tissues, J Biol Chem, 1957, 226, 497-509.

27 Zlatkis, A.; Zak, B.; Boyle, A.J. A new method for direct determination of Serum cholesterol, J Lab Clin Med, 1953, 41, 486-492.

28 Van Handel, L.; Zilver Smith, D.B. Micro method for direct determination of serum triglycerides, $J$ Lab Clin Med, 1957, 1550, 152-162.

29 Bartlett, G.R. Phosphorus assay in column chromatography. J Biol Chem, 1959, 234, 466-468.

30 Dubois, M.; Gilles, K.A.; Hamilton J.K.; Rebers, P.A.; Smith, F. Calorimetric method for the determination of sugars and related substances, Anal Chem, 1956, 28(3), 350-356.

31 Berson, S.A.; Yellow, R.S. General principles of radioimmunoassay, Clin Chem Acta, 1968, 22, 5159.

32 Chaudhary, D.P.; Boparai, R.K.; Bansal, D.D. Implications of oxidative stress in high sucrose low Magnesium diet fed rats, Eur J Nutr, 2007, 46(7), 383-390.

33 Boparai, R.K.; Kiran, R.; Bansal, D.D. Insinuation of exacerbated oxidative stress in sucrose fed rats with a low dietary intake of magnesium: evidence of oxidative damage to proteins, Free Radic Res, 2007, 41(9), 981-989.

34 Dulloo, A.G.; Seyloux, J.; Girardier, L.; Chantre, P.; Vandermander, J. Green tea and thermogenesis: interaction between catechin polyphenols, caffeine and sympathetic activity, Int $J$ Obes Relat Metab Disord, 2000, 24, 252-258.

35 Murase, T.; Nagasawa, A.; Suzuki, J.; Hase, T.; Tokimitsu, I. Beneficial effects of tea catechins on diet-induced obesity: stimulation of lipid catabolism in the liver, Internatonal journal of obesity, 2002, 26, 1459-1464.

36 Gomes, A.; Vedasiromone, J.R.; Das, M.; Sharma, R.M.; Ganguly, D.K. Antihyperglycemic effect of black tea in rat, J Etyhnopharmacol, 1994, 45, 223 226.

37 Chakravarthy, B.K.; Gupta, S.; Gode, K.D. Functional beta cell regeneration in the islets of pancreas in alloxan induced diabetic rats by (-)epicatechin, Life Sci 1982, 31, 2693-2697. 
38 Walter-Law, M.E.; Wang, X.L.; Law, B.K.; Hall, R.K.; Nawano, M.; Granner, D.K. Epigallocatechin gallate, a constituent of green tea, represses hepatic glucose production, J Biol Chem, 2002, 277, 34933-40.

39 Sebokovo, E.; Klimes, I.; Gasperikova, D.; Bohov, P.; Langer, P.; Lavau, M. Regulation of gene expression for lipogenic enzymes in the liver and adipose tissue of hereditary hypertriglyceridemic, insulin resistant rats: Effect of dietary sucrose and marine fish oil, Biochim Biophys Acta, 1996, 1303, $56-62$.

40 Kono, S.; Shinchi, K.; Ikeda, N.; Yanai, F.; Imanishi, K. Green tea consumption and serum lipid profiles: a cross-sectional study in northern Kyushu, Jpn Prev Med, 1992, 21, 526-31.

41 Chan, P.T.; Gong, W.P.; Cheung, Y.L.; Huang, Y.; Ho, O.K.; Chen, Z.Y. Jasmine green tea epicatechins are hypolipidemic in hamsters fed a high fat diet, J Nutr 1999, 129, 1094-1101.

42 Broadhurst, C.L.; Polansky, M.M.; Anderson, R.A. Insulin-like biological activity of culinary and medicinal plant aqueous extracts in vitro, J Agric Food Chem, 2000, 48, 849-852.

43 Anderson, R.A.; Polansky, M.M.; Tea enhances insulin activity, J Agric Food Chem, 2002, 50, 7182-7186.

44 Kao, Y.H.; Hiipakka, R.A.; Liao, S. Modulation of endocrine systems and food intake by green tea epigallocatechin gallate, Endocrinology, 2000, 141, 980-987. 